\title{
Competitive Analysis: Chicken Meat Sector in Brazil and Turkey
}

\section{Sahinli MA1* and Abdul-Kareem MM²}

${ }^{1}$ Agricultural Faculty Agricultural Economics, Ankara University, , Ankara, Turkey

${ }^{2}$ Doctorate Student, Ankara University, Department of Agricultural Economics, Turkey

*Corresponding Author: Mehmet Arif Sahinli, Agricultural Faculty Agricultural

Research Article

Volume 3 Issue 3

Received Date: May 21, 2018

Published Date: June 27, 2018

Economics, Ankara University, Ankara, Turkey; Tel: + (90) 31259614 77; Email: asahinli@ankara.edu.tr

\section{Abstract}

The purpose of this study is to investigate the competitiveness of the Turkey and Brazil poultry meat sectoring the international arena. The study used annual data from 2010-2014. The Comparative Advantage Index (RCA) for poultry meat sector is calculated using the Balassan Index approach. According to the results obtained Brazil has a higher comparative advantage in poultry meat production than Turkey. However, it is observed that while the RCA index values of Turkey are steadily increasing in trends over the years, Brazil values are decreasing particularly between 2011 and 2013.

Keywords: Competitive Advantage; Balassan Rca; Chicken Meat Sector; Turkey; Brazil

Abbreviations: CAI: Comparative Advantage Indices; GMP: Good Manufacturing Practices; HACCP: Critical Control Point: PNSA: Poultry Health Program; SOP: Standard Operation Procedures.

\section{Introduction}

Competition is increasingly becoming importance in today's world. For countries to improve on their efficiency to able to market their products in the world market successfully, they have to increase their competitive power. Competitive advantage is considered an organised nature of a nation's production skills and capacity increment. One of the main goals of measuring international competitive advantage countries in products is to establish the performance of the firms, sectors and a countries'economies.

\section{Poultry Production Stages can be Put Under the Following Headings}

-Economy; In this poultry meat production process, the chicken protein producing animals consumes less water. Approximately 3,900 litres of water are required to produce $1 \mathrm{~kg}$ of poultry meat. From the growth stage to the final product, beef and pork production requires 15,500 litres and 4,800 litres respectively [1].

\section{Continuity}

The production of chicken meat has the lowest impact on global warming. An environmental impact study on meat revealed that the production of other meats produces volumes of greenhouse gases four times that of poultry [1]. 


\section{Food Science and Nutrition Technology}

\section{Halal}

Most of Brazilian slaughter houses have got "halal" slaughter certificates which are recognised by the Islamic authorities [1].

\section{Product}

The various parts of the animal from foot to skins are used as organic fertilizer in agriculture. Again poultry skin and oil are used in the production of biodiesel and a supplement in cats and dogs feeds [1].

\section{Environment}

Poultry meat production has least impact on the soil. In a study undertaken, it was concluded that in poultry meat production eutrophication and acidification levels were four times lower than those resulting from the production of pork and beef [1].

There have been studies on the measurement of comparative advantages and competitiveness by quite a number of researchers [2-8].

In this study, we aim at investigating the changes occurring in the Turkey and Brazil poultry meat industry's comparative advantages and competitiveness in the world market. Considering the range of data used in the research, and in the wake of the economic crisis that occurred in the years 2008 and 2009 it is observed that what happened and afterwards negatively affected the proportion of poultry meat sector contribution to the Turkey's economy. To determine the comparative advantages and competitiveness of the sector, Comparative Advantage Indices (CAI) for the poultry meat sector have been calculated.

In the 1980s, Brazil began merger of the poultry industry. Broiler meat export to Japan almost doubled [9]. In the 1990s, more advanced technology was employed in the production of broiler meat which brought about higher production levels. As a result competitiveness increased in the country which culminated in high efficiency, new technology usage and reduction in production cost. At the same time, the internationalization process in the South of Brazil observed the emergence of important companies $[9,10]$. Towards the end of 1990s, Brazil began exporting processed poultry products to Europe and particularly meat products were given special attention [11].

The threat of competition offensive elements in the Brazilian poultry meat sector, since 1999 has been various mergers and acquisitions of firms. The largest company Sadia and Perdigno small firms or players. Sadia Company in 1999 acquired 90\% stake in Granja Resend's investment with 109 \$million. The merger of Sadia and Perdigno is a dangerous process for competition. The antitrust authority in Brazil foresees that the future of the merger of these two firms could be dangerous to the poultry meat industry but did nothing to prevent its formalisation. In Brazilian system the operation of Sadia and Perdigno showed good results. These companies have made their own eggs and fattening farm animals. Sadia and Perdigno are directly responsible for the companies' transactions, sales and marketing activities. At the same time, all of the inputs needs of small farmers are supplied. In addition, credit, technology, raw materials, consultancy, veterinary services and the provision of training and supplies [12].

The numbers of countries that import poultry meat from Brazil in 2000 were 81 and increased to 146 in 2009. This growth is continuous and shows Brazil's industrial capacity in new market entry. Moreover, the volume of exports between the period of 2000 and 2009 increased by $275 \%$ [13]. In 2005 Brazil became the $5^{\text {th }}$ largest country in the world in terms of population with 181.4 million people, which corresponds to $2.9 \%$ of the world's population. Brazil produces only about $1.9 \%$ of world GDP, and with exact measurement it takes the $9^{\text {th }}$ position. In 2005, it became a middle income country with GDP per capita Purchasing Power Parity of $\$ 8,563$ [12]. The world competitiveness index and a country's competitive strengths are evaluated by different criteria and published yearly by the World Economic Forum. Out of 117 countries in 2005 , Brazil was placed in $57^{\text {th }}$ and $4^{\text {th }}$ among 21 countries in Latin America. Chile and Colombia have bypassed indicating that Brazil's relative competitive position fell over the last years [12].

In 2007, the poultry meat industry in Brazil became the second largest exporter in the agriculture sector and $5^{\text {th }}$ in Brazil Total Export product (transport resources, oil and gas, minerals, soybeans and products), Brazil exports poultry products to more than 100 countries and constitutes $1.5 \%$ of GDP with 4 million people employed in the sector [14]. The poultry meat sector has changed in the last 10 years. The sector remains the most dynamic among all sectors [15]. The evolution in the poultry meat export sector made development apparent. Since 2004, Brazil has been the world's largest exporter and has 38\% world market share [16]. During the period between 2000-2009 when world poultry meat production was $35.6 \%$ production growth in Brazil rose to $84.3 \%$ [17]. $37 \%$ of the values of Brazil's total export are done in the Middle East. Asia imports poultry pieces from Brazil, 


\section{Food Science and Nutrition Technology}

which makes total import in Asia \%95.6. The European Union (EU) is the main market for chicken products. In 2009, Brazil total exports of salted and processed poultry meat were $4.7 \%$ and 5.4\%, respectively [13]. From 1990 to 2009 Patricio (2011) [9] analysed data from all broiler production companies in Brazil (a total of 4.6 billion birds have been evaluated). It was concluded that daily weight gains increased by $30 \%$, feed conversion rate decreased by ( $R \$ 0.205 \$=U \$ 0.101)$, live weight increased by $28.4 \%$ and liveability decreased by $2.0 \%$. According to Mendes (2010) [18], Brazil is the 7th largest world producer of eggs. In 2011, the country produced 2.7 billion dozen eggs, which correspond to an increase rate of $4.3 \%$ over the previous years (IBGE, 2007). Brazil is currently the 3rd broiler meat producer and $7^{\text {th }}$ in egg production. At the same time, Brazil is the world's largest broiler meat exporter since 2004. This strong growth has emerged as a result of compatibility of animal feed with industrial development [19]

The Brazil poultry meat industry currently employs more than 4.5 million people with 1.5\% GDP. Brazil is the $3^{\text {rd }}$ largest poultry meat producer following closely behind China in the $2^{\text {nd }}$ position. In 2010, while Brazil broiler meat production was at 12.23 million tons, China and the United States (world production leaders) were 12.55 and 16.56 million tons respectively [1]. According to the estimate of the Brazilian Ministry of Agriculture, Livestock and Food, the country's maize and soybeans production is predicted to increase from 2011 to 2020/2021 each year up to $2 \%$ and $2.5 \%$ respectively. The same resource used in broiler meat production, domestic consumption and exports in the same period each year, $2.6 \%, 2.5 \%$ and $2.9 \%$ respectively [20].

Brazil future years' grain production is favoured by resources as the availability of large production area and potential water. According to Junior and Bruno (2012) [19], concerning growth there are still some bottlenecks and challenges. The infrastructure problems are logistics, low quality education system, producer's lack of capital, high credit costs, high social and labour obligations, high tax burdens and bureaucracy. Brazil is the world's largest beef exporter. At the same time it is the supplier of international sugar, coffee, orange juice, ethanol, tobacco and chickens. In world ranking, it is the second largest exporter of soybeans and ranks $4^{\text {th }}$ in pork and cotton exportation. The paramount reason for the increase in agricultural success is Brazil's natural advantages alongside long term State or Government policies on investment in research and training opportunities. The advantages of Brazil are; the available suitable climate which can support two or more products, pair products can be obtained, wide and large production area, abundance of water supply, various types of soils and climate that can enhance technology and product diversity [20].

Brazil's Poultry Producers and Exporters Association (ABEF) is said to be responsible for $90 \%$ of the Poultry exports which are done by 23 companies. The mission of $\mathrm{ABEF}$ is to ensure poultry export development, new market entry, and to make them the world largest producer and exporter of quality poultry products [14]. The competitive advantages Brazil's (for All meats) are integrated production systems and up-to-date technology, competitive internal market, worldwide companies and brands, ideal natural conditions for the production, sufficient maize and soya bean feed for animals, the European Union and Japan recognized health system and the importance given to health protection (Lohbauer C., 2008).Biological security operations in Brazil; bird flu prevention national plan and new disease prevention, banned on the import of live infected animals, the intensity of checks and systematic pathogenic analysis that are done at bird migration points [14].

In Brazil there is no subsidy for continuous poultry production; small family farming, global agriculture, communication system, poultry production, soya bean and maize with nested and less electric, use less artificial hearing as needed [21]. According to Hartog (2003) [22], feeding and food security concept increase each year. Also Anaruma (2009) [23] states that good manufacturing practices (GMP) and Hazard Analysis and Critical Control Point (HACCP) systems are supported by the State.

During slaughter and processing, health inspection is done by State/Government veterinary. The control service is called the Federal inspection. In the poultry industry, Brazil government has two major systems for health checks. These programs have become international benchmarks. The first one is the National Poultry Health program (PNSA) which deals with bird diseases. The other is the checks on contagious ruins and the national plan (PNCRC). Both programs are compatible with the OIE and Codex Alimentarius Standards. In addition, companies implement health programs and interventions. These are internationally recognized programs. The Programs are Hazard Analysis and Critical Control Points (HACCP) programs, Health Standard Operating Procedures (SSOP) programs and Standard Operation Procedures (SOP). Because of these programs, Brazil is among the leading countries in the production and export of poultry in the world. In addition, there have not been cases of bird flu [1]. 
Rabo bank is a popular bank in the Netherlands, which was founded in 1972 and specializes in the agricultural sector. This bank estimates that world meat demand will reach $44 \%$ and 4000 million tons annually by 2030 . The highest growth will occur in the poultry meat consumption by $60 \%$ and this figure will correspond to $39 \%$ of the world demand for meat in 2030. Despite the growth and increasing importance of the poultry sector, countries in order to protect their local industries have resorted to establishing various types of unfair barriers [1].

In a study done by FAO and OECD, it was reported that within the next 10 years, poultry meat consumption will increase in reference to the preferred meat, especially beef. These forecasts dependent on increase cost of poultry meat production, compliance with global demand and increasing sound strong health standards. According FAO/OECD, demand for animal protein will increase appropriately as it emits far less volume of greenhouse gases. This implies increasing Brazil's own production to $40 \%$ by 2018 is non-negotiable. It is observed that Brazil annual rate is required to increase by approximately $4 \%$ yearly [1].

The future of world demand for poultry meat will grow faster in population of developing countries, GDP growth is higher in developing countries, increases the rate of urbanization developing countries and middle class protein consumption will increase [21]. Poultry rearing under the livestock sector in Turkey started to develop in the 1970s. Particularly after the 1980s, an important production branch was developed to meet the country's poultry needs. In Turkey's broiler production, since 2013 about 1,760,000 tonnes volume of poultry meat are produced and ranks $8^{\text {th }}$ in the world. Since 2010, the first three highest producers are USA, China and Brazil. The poultry industry in Thailand has the availability of partnership with foreign capital investment. In broiler production; integrated production is very important which is developed though the contract system. Broilers are slaughtered in modern slaughter houses and through integrated firms, marketing are provided. Chicken Salers established domestic distribution system for both full chicken and chicken parts. The chicken parts that are sold are but-chest, gizzard, neck, wing, and fillet.

According to the data of the year 2013 poultry meat production was $1,923,500$ (tonnes). In this production, broiler meat was $93.14 \%$, Village Layer sand other poultry meats $4.60 \%$ turkey meat $2.29 \%$ were established. That same year, again while turkey meat production compared to the previous year decreased at a rate of $3.08 \%$ broiler meat production increased by $4.49 \%$ in the same period.

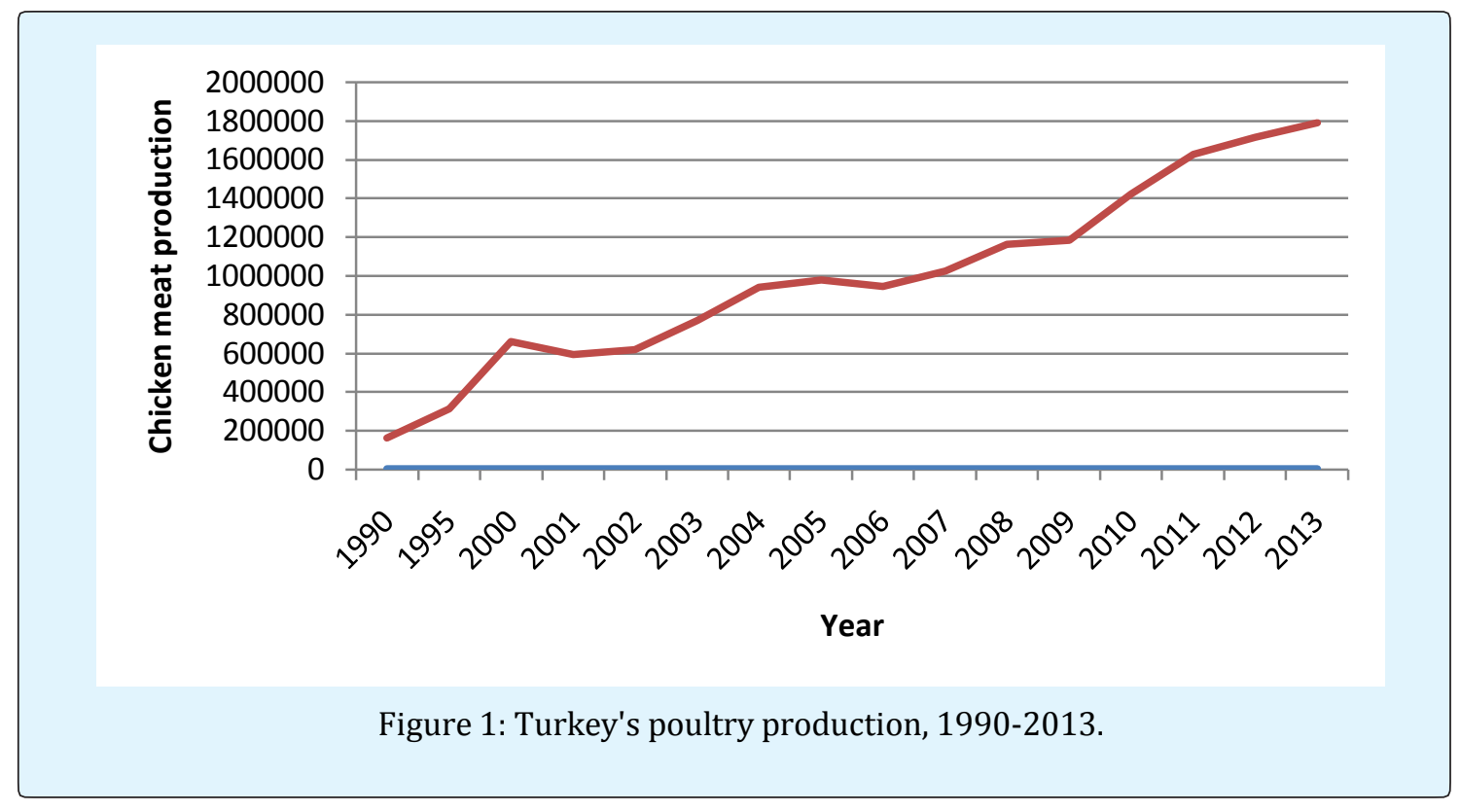

According to BESD-BIR data, between 1990 - 2013 poultry production in the year 2006 decreased at a rate of $3.33 \%$ reference to the previous year was recorded. The graph showed an increasing trend in the subsequent years as seen in Figure1. The reason for this reduction in production that year was due to the occurrence of bird flu cases. According to the growth rate in 2001, 2006 and 2009 low production figures were observed. Particularly, 
in 2001 and 2009 the low figures observed were attributed to the Turkey and world economic crisis.

The nature of Turkey's poultry production fluctuations is depicted in the figure below. The reasons behind this kind of shape are; increased price of substitution goods; income level; preference for healthy eating, etc. In particularly the emphasis on white meat as best choice made people prefer it to chicken.

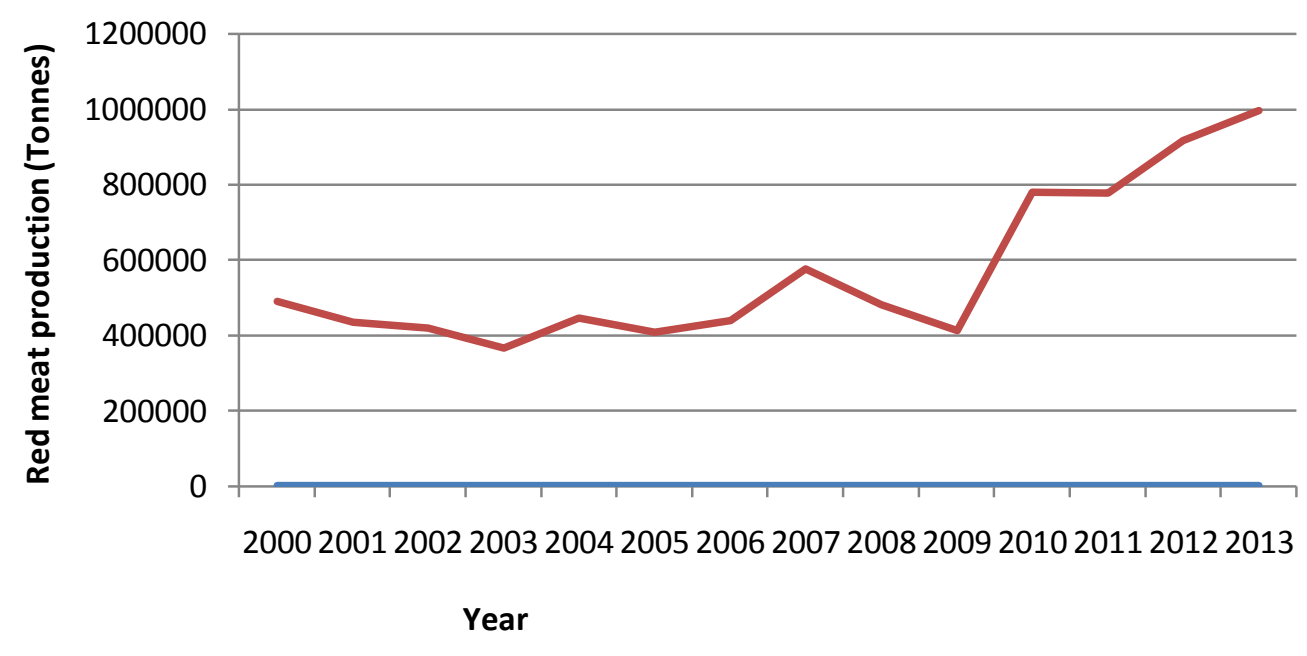

Figure 2: Production of red meat, Turkey, 2000-2013.

(Figure 2) above shows the serious fluctuations in red meat production in Turkey. It is observed that the most important factors that affect the production of meat are consumers' income level and the number of animals that are supplied. It is seen that in the year 2013 Turkey'sred meat production increased at a rate of $102.78 \%$ according to the year 2000 figure.

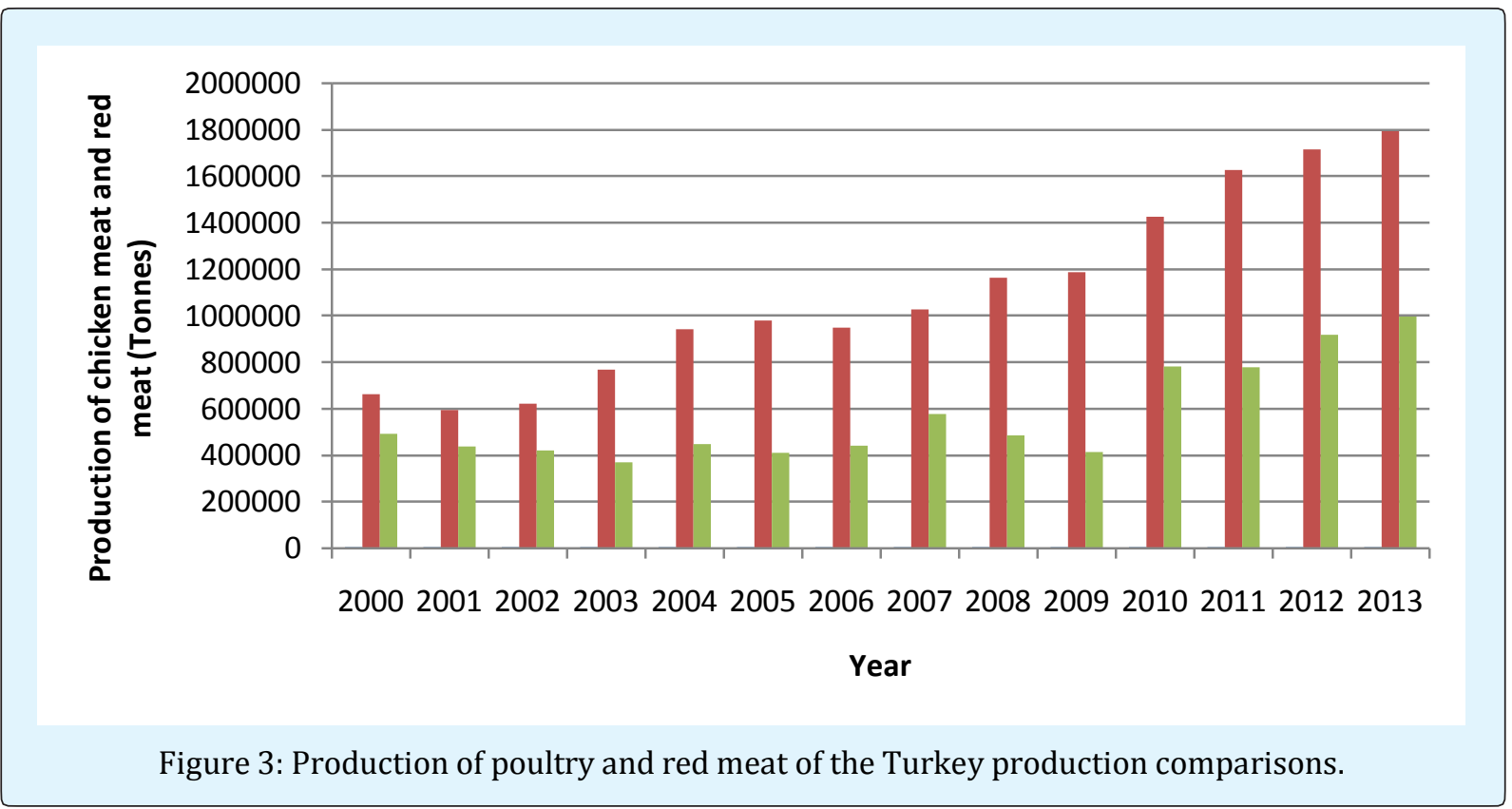


The values of white and red meat production in Turkey from2000-2013 have been compared. Figure 3 shows the serious potential of poultry meat production. The consumption of poultry meat in Turkey with the exception of $2004-2006$ and 2008 - 2009 has shown an increasing trend. Chicken meat consumption for the years specified in a horizontal navigational tracking can be attributed to various diseases and economic conjuncture (Figure 4).

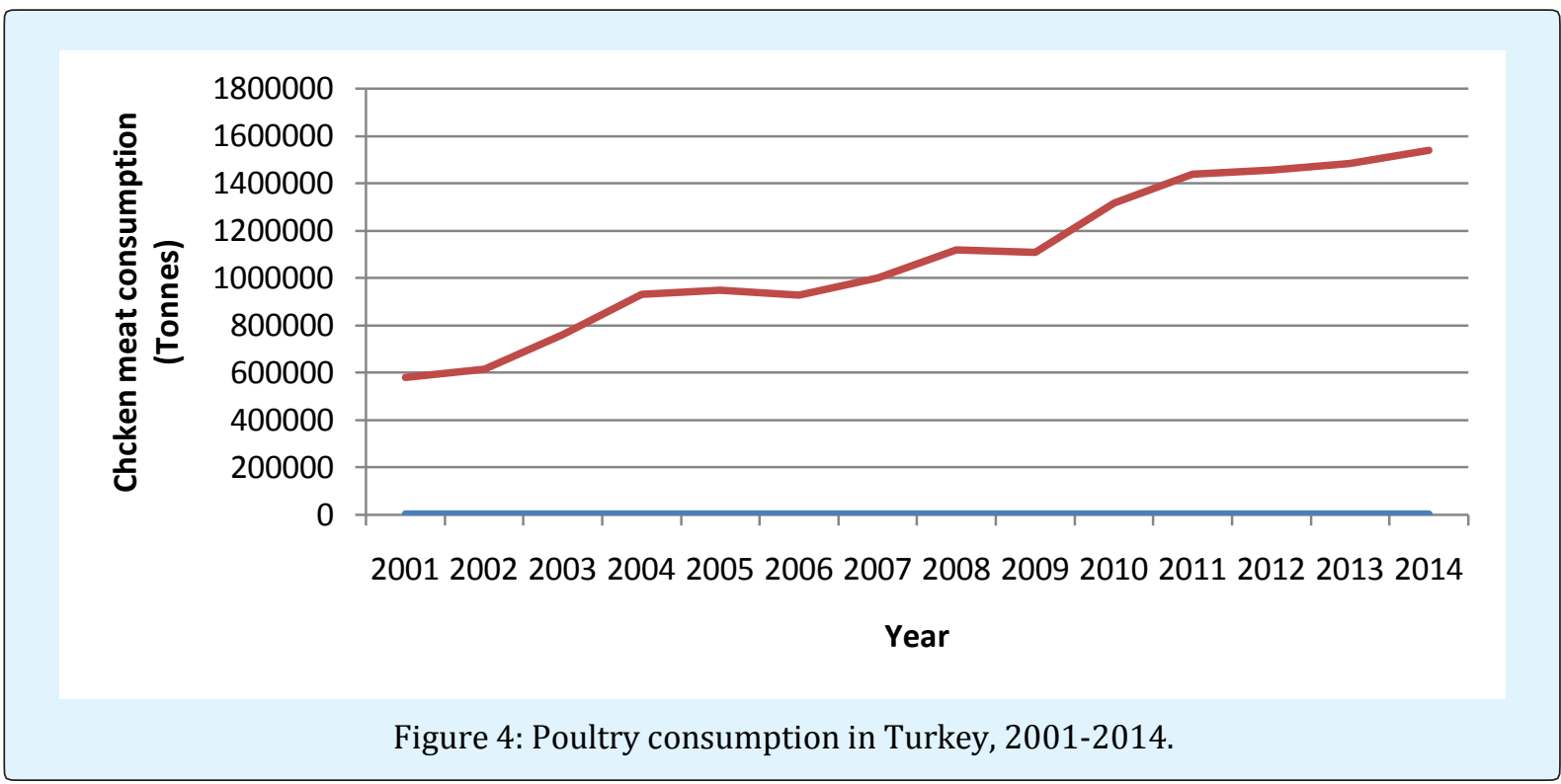

According to data on the per capita meat consumption of some selected countries in the world in 2012, in respect of meat production Turkey, Thailand and Vietnam were in the same category. Turkey 2012 per capita meat consumption data showed that poultry meat productions were $19.39 \mathrm{~kg}$ with $59.83 \%$ proportion, beef production was $11.37 \mathrm{~kg}$ representing a proportion of $35.08 \%$, sheep meat production was $1.65 \mathrm{~kg}$ with $5.05 \%$ proportion. Red meat consumption has remained well behind the white meat consumption. There are so many demand factors that hinder the rise of per capita meat consumption in Turkey. This is shown in Figure 5 below.

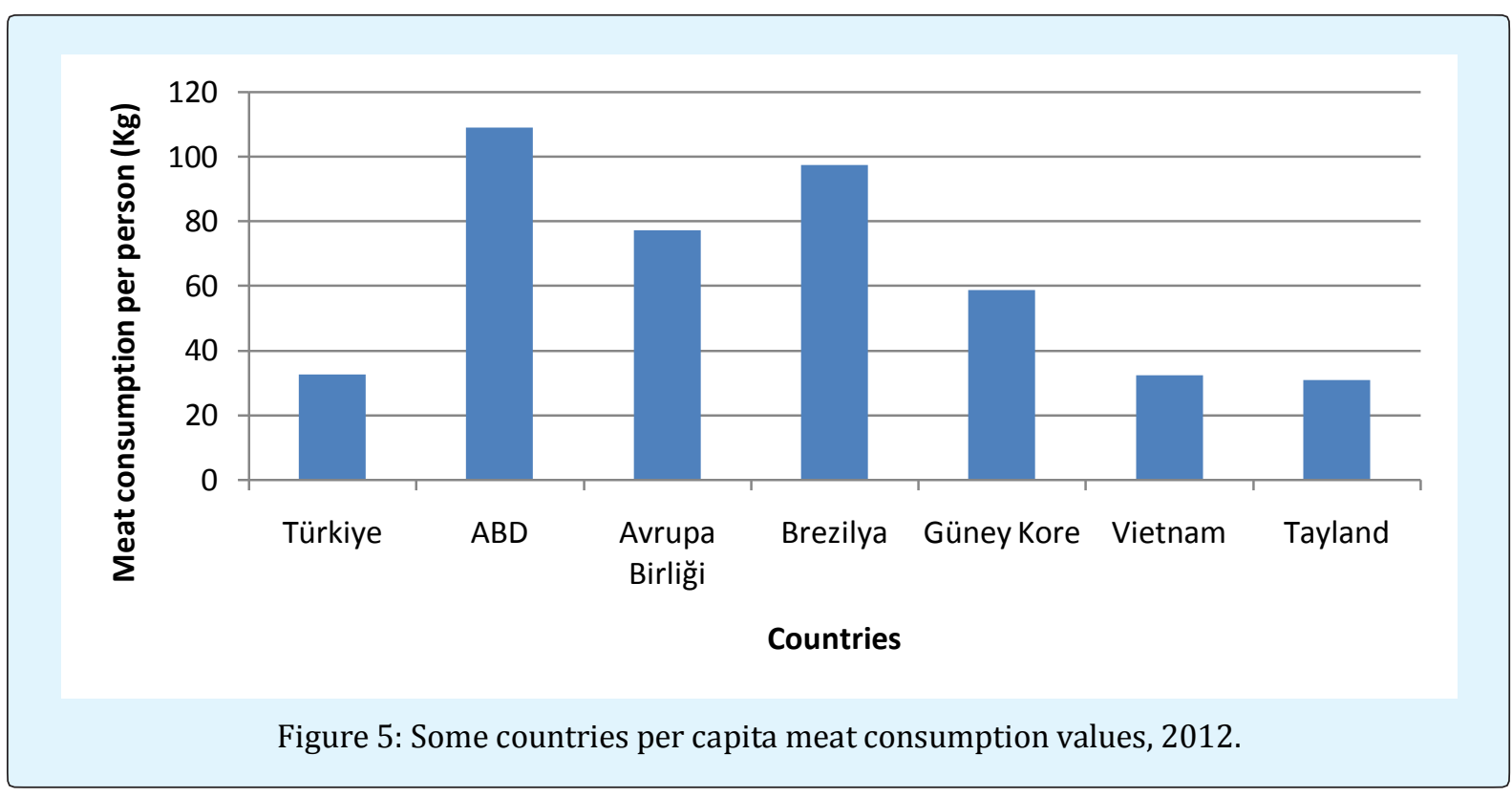


The distribution curve of poultry meat export and import for some selected countries has been investigated for the year 2014. Turkey is poultry meat exporting country while the surrounding countries are importers. This situation poses a very great opportunity for Turkey in terms of market potential which can increase its export value. Among the major exporting countries in the world, Brazil is the leader while countries like USA, European Union, Thailand, Turkey and other countries follow. In 2013 world poultry meat export were Brazil $34.45 \%$; USA 32.27\%; EU 10.54; Thailand 5.20\%; China 3.99\%; Turkey $3.51 \%$ and others $10.05 \%$ (Figure 6).

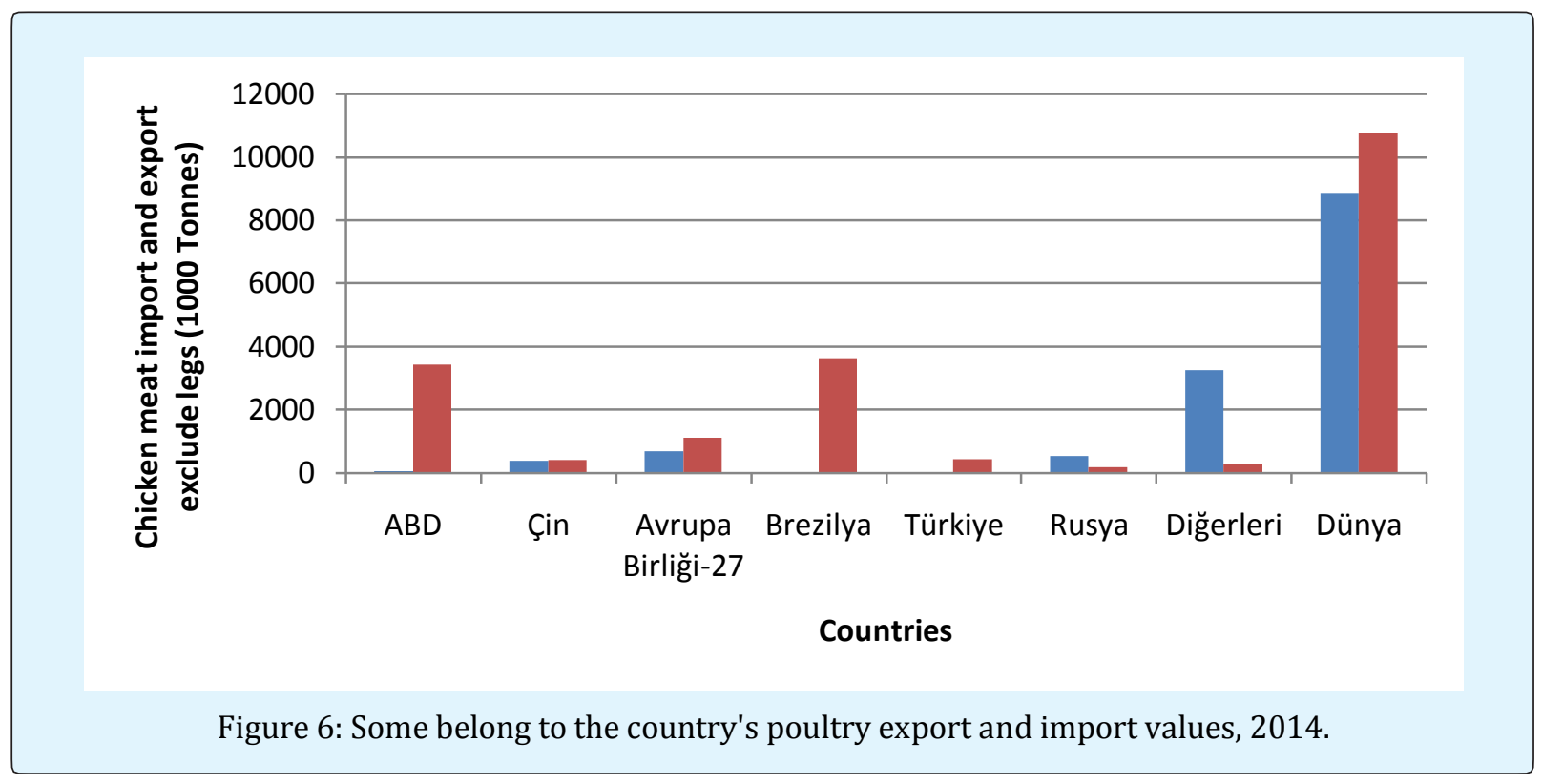

Turkey's poultry meat exports are separated into categories chicken, turkey, feet and other processed products. According to data of the year 2013, Turkey poultry meat exports were 395,694 tonnes. The composition of this export was chicken $81.48 \%$, feet $10.62 \%$, processed products $6.05 \%$, turkeys $1.70 \%$, and other poultry products $0.13 \%$. The share of Turkey's 2013poultry meat export with the exception of chicken feet were $62.34 \%$ Iraq, $10.52 \%$ Turkic Republics,7.48\% Syria, $2.97 \%$ Libya, and $1.27 \%$ and $0.56 \%$ other countries. At this point it can be said that both religion and geopolitical position of Turkey has influence its export of poultry meat to its close neighboring countries.

In addition, the value of Turkey export to other countries with the exception of poultry feet stands at $620,621,000$ US\$. It is revealed that the poultry meat export excluding poultry feet has the largest share of quantity in proportion Iraq 73.24\%, other African countries $6.31 \%$, Turkic republics and other countries 6.03\%. Iraq, Turkish Republics, Syria, Libya, Saudi Arabia and Iran are seen as important marketing partners, but these countries' demands for product variation and bilateral relations will be an important anchor for future export targets. Russia denial of export permit to EC countries has resulted in preference of the Brazilian export beside the increase in own investment. This action would inevitably bring about a narrower market for other countries.

Despite China being the most demanding country for poultry feet, the absence of export permits produces difficulty in marketing at the point of direct export. Countries like Pakistan, Japan and Egypt are important countries that put Turkey's export on its feet. Although limited export at Turkey, Jordan and Egypt when talking about export to Japan and EU were zero as of 2012. Turkey's exports to Jordan and Egypt, albeit limited to Japan and the European Union, while the exports in question as of 2012 is zero. The greater part of this market is dominated by Brazil. In this regard comparing Turkey and Brazil comparative advantage with urgency in order to exam and take measures increasing the export value is a possibility.

\section{Materials and Methods}

The study adopted one of the most widely used indices; Balassa Index of Revealed Comparative Advantages (BIRCA).With the Balassa Approach, it is 
assumed that the actual Comparative Advantage can be observed from the data after trading [24-26]. This approach works to determine whether the goods or industry of a country has comparative advantage.

Balassa Index can be formulated as follows:

$\operatorname{BIRCA}_{\mathrm{ij}}=\left(\mathrm{xij} / \mathrm{X}_{\mathrm{j}}\right) /(\mathrm{xiw} / \mathrm{Xw})$

where BIRCA $_{\mathrm{ij}}$; represents $j$ th country's Balassa Index Relative Comparative Advantage in the ithgoods.

xij: j country's ith export goods

XJ: j country's total exports

xiw: it good world export

$\mathrm{X}_{\mathrm{w}}$ : Total World Exports

When BIRCA $>1$, it implies $j$ th country has comparative advantage in $i$ th good. This means that the share of the goods in the country's total export is greater than world trade share. I mean, the goods in the country's total exports, is greater than the share of world trade. If BIRCA $<1$, it means the goods has a comparative disadvantage.

\section{Results and Discussion}

The BIRCA Index for 2010 - 2014 years has been calculated and provided in the Table 1 below. According to these values Turkey is $6^{\text {th }}$ in comparative advantage in the poultry meat production sector worldwide. Brazil is $1^{\text {st }}$ and has protected this position over the years. In 2010 Turkey comparative advantage in poultry meat was 1.55 while 2014 was 4.10 . In the same year (2010), Brazil was 27.51 and 28.74 in 2014.

\begin{tabular}{|c|c|c|c|c|c|}
\hline Countries & $\mathbf{2 0 1 0}$ & $\mathbf{2 0 1 1}$ & $\mathbf{2 0 1 2}$ & $\mathbf{2 0 1 3}$ & $\mathbf{2 0 1 4}$ \\
\hline Brazil & 27.51 & 25.34 & 25.85 & 25.92 & 28.74 \\
\hline EU & 0.3 & 0.32 & 0.33 & 0.32 & 0.31 \\
\hline Thailand & 3.89 & 4.26 & 4.41 & 4.34 & 4.31 \\
\hline China & 0.41 & 0.42 & 0.36 & 0.34 & 0.36 \\
\hline Turkey & 1.55 & 2.74 & 3.26 & 3.88 & 4.10 \\
\hline Argentina & 5.61 & 5.01 & 6.92 & 7.03 & 8.49 \\
\hline Ukraina & 0.76 & 1.18 & 1.97 & 4.01 & 4.83 \\
\hline Canada & 0.63 & 0.60 & 0.55 & 0.57 & 0.50 \\
\hline Belarus & 2.55 & 3.37 & 4.07 & 5.08 & 5.79 \\
\hline Chilli & 1.94 & 2.12 & 2.09 & 2.04 & 2.00 \\
\hline Others & 0.06 & 0.07 & 0.07 & 0.07 & 0.07 \\
\hline USA & 4.07 & 4.03 & 3.82 & 3.80 & 3.65 \\
\hline
\end{tabular}

Table 1: The index values calculated for BIR Index chicken meat, 2010-2014.

The BIRIndex value indicates a country's competitive advantage, the higher the index value the greater the competitive edge of the country. It is observed from the graph in figure 7 that while Turkey's chicken meat production BIR Index value was increasing continuously Brazil's index was in the descent from $2011-2013$.

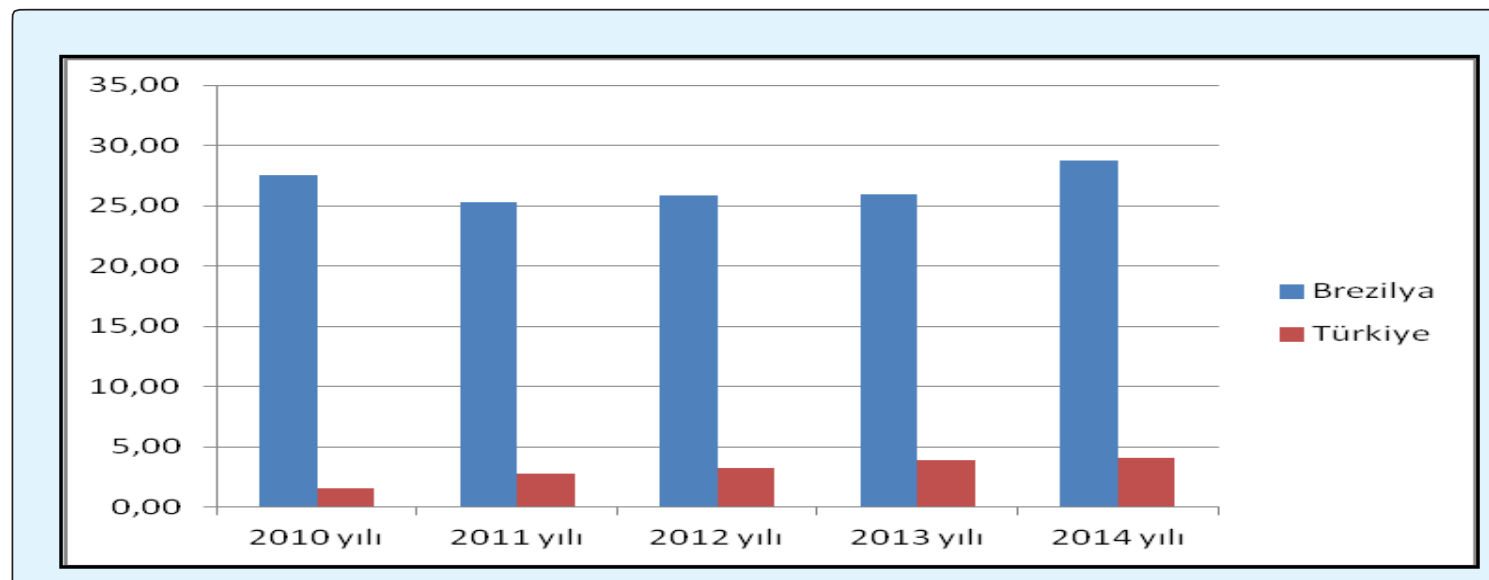

Figure 7: Comparison of the calculated BATTERY value for chicken meat, Turkey and Brazil. 
Turkey has enough experience in competition in the world market. It has a good knowledge of its geographical position, well educated, and skilled labour force, the availability of sufficient and necessary infrastructure, cotton and cotton products industry and present an important opportunity for the industry. However, there are other factors that can negatively affect the competitive strength of this sector.

Turkey's poultry export has various advantages and disadvantages. Advantages include; the white meat sector return to scale so that firms reach economies of scale, technological superiority, being Muslims, geopolitical position, proximity to import countries, trained staff, the effect of the State product monitoring, quality products, palate flavour etc, can be considered. The disadvantages include; external dependence problem, feeding raw material problems, financing problem, reduced VAT, consumption scarcity, chicken hormone and antibiotic claims, the breeding problems, export and import problems and indifferent (unregistered) production problems etc.

The industry dependent on import with basic input imports. The basic inputs of the sector comprise of import of eggs and chicks, feed and vaccine industry. The increase in feed prices emerging as a factor increasing the cost of production. The import of soya bean, maize, and fish flour constitute a larger component of the raw materials. Besides chicken meat and eggs, slaughterhouses waste, rendering painting feathers and such products as meat flour can be used in the food factories. Also the poultry feet that are exported to Far East countries establishes an economic potential. With the features of poultry, the relationship of poultry rearing sector with other sectors brings about active development such that across the world in more than 50 countries poultry production plays important roles in economic development.

\section{References}

1. UBABEF (2012) Brazilian Poultry.

2. Hillman A (1980) Observation on the Relation between Revealed Comparative Advantage and Comparative Advantage as Indicated by Pre-Trade Relative Prices. Welt wirts chaft liches Archiv, 116(2): 315-321.

3. Bowen H (1983) On the Theoretical Interpretation of Trade Intensity and Revealed Comparative
Advantage. Weltwirtschaftliches Archive 119(3): 464472.

4. Kojima K (1970) The Pattern of International Trade among Advanced Countries. Hitotsubashi Journal of Economics 5(1): 16-36.

5. Şahinli MA (2011) Açılklanmış Karşılaştırmalı Üstünlükler Endeksi: Türkiye Pamuk Endüstrisine Bir Uygulama. Selçuk Üniversitesi İktisadi ve İdari Bilimler Fakültesi Sosyal ve Ekonomik Araştırmalar Dergisi 15(21): 237-249.

6. Şahinli MA (2013) Comparative advantage of agriculture sector between Turkey and European Union. African Journal of Agricultural Research 8(10): 884-895.

7. Şahinli MA (2012) Rekabet Gücü: Türkiye ve Avrupa Birliği Üyesi Ülkelerde Canlı Hayvancıllk Sektörünün Durumu. Yüzüncü Yıl Üniversitesi Tarım Bilimleri Dergisi 22(2): 91-98.

8. Şahinli MA (2014) Revealed Comparative Advantage and Competitiveness: Turkey Agriculture Sector. Yüzüncü Yıl Universities Tarım Bilimleri Dergisi 24(3): 210-217.

9. Patricio IS (2011) Vinte anos do desempenho de frangos nas condiçoes brasileiras. In: Anais da Conferencia FACTA 2011 de Ciencia e Technologia Avicolas. Santos, SP, Brasil, 91-112.

10. Dambros DA (2010) avicultura no Brasil.

11. Mior LC (2005) Agricultores Familiares, Agroindustrias e Redes de Desenvolvimento Rural. Chapeco: Argos pp 338.

12. Bustelo F, Dutzler B, Kogut J, Savanti P, Severin R (2006) Chicken run in goias the poultry cluster in Brasil, Harvard Business School.

13. Oliveira CA, Vitor DC, Finger MI, Waquil PD, Anselmi A, et al. (2012) Developments of the Brazilian Chicken Meat Industry in International Trade: Analysis with Industrial Organization, Center for Studies and Research in Agribusiness, Federal University of Rio Grande do Sul - Brazil.

14. Lohbauer C (2008) Brazilian Chicken Production \& Worldwide Trade, Fodex.

15. FAO (2010) Agribusiness handbook: poultry meat and eggs 6. 
16. USDA (2010) United States Department of Agriculture. Livestock and Poultry: world markets and trade.

17. USDA (2011) United States Department of Agriculture. Production, supply and distribution.

18. Mendes AA (2010) Avicultura Brasileria: Avanços, gargalos e desafios. In: Anais da Conferencia FACTA 2010 de Ciencia e Technologia Avicolas. Santas, SP, Brasil 123-138.

19. Junior AMP, Bruno DG (2012) Centre for Studies and Research in Agribusiness, Federal University of Rio Grande do Sul - Brazil.

20. Economist Intelligence Unit Limited (2010) the global power of Brazilian agribusiness.

21. Santin R (2013) Brazil's poultry industry: building partnerships around the world, Brazilian Poultry Association - UBABEF.
22. Hartog J den (2003) Aplicaçao de HACCP na produçao de dietas para animais. Seminario realizado em In: Relatorio PAT 2003. Embrapa Suinos e Aves. Concordia SC.

23. Anaruma RJ Site da Associaçao Brasileira de Zootecnistas (2009) Boas-prticas-fabricao-APPCCestabelecimento-produtos-destinados-alimentaoanimal.html.

24. Balassa B (1965) Trade Liberalization and Revealed Comparative Advantage. Manchester School of Economic and Social Studies 33(2): 99-124.

25. IBGE (2012) Instituto Brasileiro de Geografia e Estatistica. Abates de frangos e suinos e produçao de leite e ovos crescem em.

26. MAPA (2011) Ministério da Agricultura Pecuária e Abastecimento. 2010. Projeções do Agronegócio Brasil.

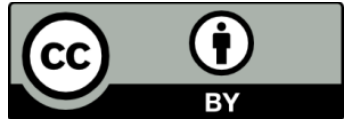

